\title{
PENGARUH MODEL PEMBELAJARAN NUMBERED HEAD TOGETHER (NHT) TERHADAP PENINGKATAN KEMAMPUAN PEMAHAMAN KONSEP BERBANTUAN SOFTWARE
}

\section{THE EFFECT OF NUMBERED HEAD TOGETHER (NHT) LEARNING MODEL USE A SOFTWARE ON IMPROVING THE CONCEPT UNDERSTANDING ABILITIES}

\author{
ZULAINI MASRURO NASUTION
}

\begin{abstract}
STIKOM Tunas Bangsa Pematang Siantar, Pematang Siantar
\end{abstract} email:zulaini@amiktunasbangsa.ac.id

\begin{abstract}
Abstrak
Penelitian ini bertujuan untuk mengetahui ada tidaknya pengaruh model pembelajaran Numbered Head Together terhadap kemampuan pemahaman konsep siswa kelas X SMK Teladan Pematangsiantar tahun 2020 sebelum diberi perlakuan (pretes) dan sesudah diberi perlakuan (postes) pada kelas eksperimen. Penelitian ini merupakan penelitian eksperimen semu.Populasi dalam penelitian ini adalah seluruh kelas X SMK Teladan Pematangsiantar yang berjumlah 74 orang.Sedangkan sampel yang digunakan pada penelitian ini berjumlah 37 orang.Sampel penelitian ditentukan dengan teknik simple random sampling.Pengumpulan data dengan menggunakan teskemampuan pemahaman konsep dengan soal uraian berjumlah 5 butir. Data di analisis menggunakan uji normalitas dan ujihi potesis yaitu paired simples t-test . Hasil penelitian menunjukkan bahwa terdapat pengaruh model pembelajaran Numbered Head Together terhadap kemampuan pemahaman konsep siswa dari uji pretes dan postes yang diberikan pada siswa kelas $\mathrm{X}$ SMK Teladan Pematangsiantar. Rata-rata nilai posttest adalah 44,67 lebih tinggi dari nilai pretest 18,56 dan presentase kenaikannya adalah $13 \%$. Adanya perbedaan yang signifikan menunjukkan bahwa pembelajaran menggunakan model pembelajaran Numbered Head Together berpengaruh positif terhadap kemampuan pemahaman konsep siswa.
\end{abstract}

\section{Kata kunci: Kemampuan pemahaman konsep, Numbered Head Together}

\begin{abstract}
This study aims to determine whether there is influence of the model of learning Numbered Head Together on the ability to understand the concept of class $X$ students of SMK Teladan Pematangsiantar in the 2020 lesson years before being treated (pretested) and after being treated (postes) in the experimental class. This research is a quasi-experimental research. The population in this study is the entire class $X$ students of SMK Teladan Pematangsiantar which amounted to 74 people. While the sample used in this study amounted to 37 people. The sample is determined by simple random sampling technique. Data collection by using concept comprehension comprehension test with 5 item description. Data were analyzed using normality test and hypothesis test that paired simples t-test. The result of the research shows that there is influence of the Numbered Head Together learning model to the students' concept of pretest and post test which is given to the students of grade $X$ students of SMK Teladan Pematangsiantar. The average posttest score is 44.67 higher than the pretest value of 18.56 and the percentage increase is $13 \%$. The existence of significant differences indicate that the learning using the model of learning Numbered Head Together have a positive effect on students' concept of understanding ability.
\end{abstract}

Keywords: Ability to comprehend concept, Numbered Head Together 


\section{Pendahuluan}

Pendidikan merupakan sumber daya insani yang sepatutnya mendapat perhatian terus menerus dalam upaya peningkatan mutunya. Peningkatan mutu pendidikan berarti pula peningkatan kualitas sumber daya manusia. Untuk itu perlu di lakukan pembaruan dalam bidang pendidikan dari waktu ke waktu tanpa henti. Hal ini tertuang dalam Undang-Undang Republik Indonesia Nomor 20 Tahun 2003pasal 1 ayat 2 bahwa "Pendidikan nasional adalah pendidikan yang berdasarkan Pancasila dan Undang-Undang Dasar Negara Republik Indonesia Tahun 1945 yang berakar pada nilai-nilai agama, kebudayaan nasional Indonesia dan tanggap terhadap tuntutan perubahan zaman"[1].

Salah satu proses pendidikan adalah pembelajaran. Pembelajaran dalam hal ini dapat dilakukan pada pendidikan formal (disekolah) atau non-formal (diluar sekolah). Pembelajaran merupakan aktivitas dan proses yang sistematis dan sistemik yang terdiri dari beberapa komponen yaitu: guru, kurikulum, anak didik, fasilitas, dan administrasi. Masing-masing komponen tidak bersifat parsial atau berjalan sendiri-sendiri, tetapi harus berjalan secara teratur, saling bergantung, komplementer dan berkesinambungan. Untuk itu diperlukan rancangan dan pengelolaan belajar yang baik yang dikembangkan dalam rangka mencapai tujuan pembelajaran[2]. Salah satu pembelajaran yang sangat penting adalah pembelajaran matematika. Matematika merupakan ilmu universal yang mendasari perkembangan teknologi modern, mempunyai peran penting dalam berbagai disiplin dan dapat mengembangkan daya pikir manusia. Matematika sebagai salah satu ilmu dasar, baik aspek terapan maupun aspek penalarannya mendukung kemajuan ilmu pengetahuan dan teknologi[3]. Matematika sebagai bagian dari pengetahuan, memiliki ciri dan karakteristik tertentu yang salah satu ciri dari matematika adalah objeknya bersifat abstrak. Keabstrakan dari objek matematika sulit dihafalkan. Untuk memahami objek atau konsep matematika yang bersifat abstrak dibutuhkan keaktifan siswadalam pembelajarannya. Keaktifan siswa dalam belajar tidak lain adalah untuk mengkonstruksi pengetahuan mereka sendiri, mereka aktif membangun pemahaman atas persoalan atau segala sesuatu yang mereka hadapi dalam kegiatan pembelajaran.

Banyak faktor yang menyebabkan rendahnya mutu pendidikan matematika, ada faktor internal dan ada faktor eksternal. Faktor internal misalnya banyak siswa yang beranggapan bahwa belajar matematika itu sangatlah sulit, karena karakteristik matematika yang penuh dengan perhitungan, berfikir logis, angka-angka dan rumus-rumus yang membingungkan, faktor fisik, misalnya, keterbelakangan mental, fungsi otak yang kurang baik dan bakat seseorang. Faktor lainnya yaitu faktor eksternal, misalnya cara mengajar guru yang kurang menyenangkan sehingga siswa sulit untuk memahaminya dan kurangnya fasilitas penunjang dalam pembelajaran[4].

Namun, bagi sebagian siswa matematika merupakan mata pelajaran yang kurang disenangi. Ini disebabkan karena masih banyak siswa yang kurang terlibat dalam kegiatan proses belajar sehingga kemampuan pemahaman konsep matematis siswa kurang optimal. Padahal untuk pencapaian hasil belajar yang maksimal siswa harus mencapai ketuntasan indikator dari setiap aspek pembelajaran yang diterapkan oleh guru[5]. Hal ini juga peneliti temukan di SMK Teladan Pematangsiantar. Berdasarkan hasil observasi melalui wawancara dengan guru matematika. diketahui bahwa siswa kelas X SMK Teladan Pematangsiantar menganggap matematika itu sulit dan membosankan, tidak berpatisipasi aktif dalam proses pembelajaran atau tidak mau bertanya, siswa kurang mampu menyerap atau memahami materi yang disampaikan oleh guru yang mengakibatkan siswa tidak dapat menyelesaikan soal-soal dan mengaplikasikan pembelajaran didunia nyata maupun mengembangkan kemampuan lain yang menjadi tujuan pembelajaran matematika dikarenakan kemampuan pemahaman konsep matematis siswa rendah.

Pemahaman konsep adalah kemampuan siswa yang berupa penguasaan sejumlah materi pelajaran, dimana siswa tidak sekedar mengetahui atau mengingat sejumlah konsep yang dipelajari, tetapi mampu mengungkapan kembali dalam bentuk lain yang mudah dimengerti, memberikan interprestasi data dan mampu mengaplikasikan konsep yang sesuai dengan struktur kognitif yang dimilikinya[6]. Adapun menurut Peraturan Dirjen Dikdasmen Nomor 506/C/Kep/PP/2004 tentang rapor pernah diuraikan bahwa indikator siswa memahami konsep matematika adalah mampu [7]:

1. Menyatakan ulang sebuah konsep,

2. Mengklasifikasi objek menurut tertentu sesuai dengan konsepnya,

3. Memberikan contoh dan bukan contoh dari suatu konsep,

4. Menyajikan konsep dalam berbagai bentuk representasi matematis,

5. Mengembangkan syarat perlu atau syarat cukup dari suatu konsep,

6. Menggunakan dan memanfaatkan serta memilih prosedur atau operasi tertentu,

7. Mengaplikasikan konsep atau algoritma dalam pemecahan masalah. 
Keberhasilan siswa dalam pembelajaran matematika dapat dilihat dari kemampuan pemahaman konsep matematis. Akan sangat sulit bagi siswa untuk menuju ke pembelajaran yang lebih tinggi jika belum memahami konsep. Oleh karena itu, pemahaman konsep matematis adalah salah satu tujuan penting dalam pembelajaran matematika. Pemahaman merupakan terjemahan dari istilah understanding yang diartikan sebagai penyerapan arti suatu materi yang dipelajari. Pemahaman adalah tingkat kemampuan yang mengharapkan siswa mampu memahami arti atau konsep, situasi serta fakta yang diketahuinya. Untuk memahami suatu objek secara mendalam,seseorang harus mengetahui: 1) objek itu sendiri; 2) relasinya dengan objek lain yang sejenis; 3) relasinya dengan objek lain yang tidak sejenis; 4) relasi-dual dengan objek lainnya yang sejenis; 5) relasi dengan objek dalam teori lainnya[8].

Pemahaman konsep matematis penting untuk belajar matematika secara bermakna, tentunya para guru mengharapkan pemahaman yang dicapai siswa tidak terbatas pada pemahaman yang bersifat dapat menghubungkan. Hal ini merupakan bagian yang paling penting dalam pembelajaran matematika karena mata pelajaran matematika menekankan pada konsep. Artinya dalam mempelajari matematika peserta didik harus memahami konsep matematika terlebih dahulu agar dapat menyelesaikan soal-soal dan mampu mengaplikasikan pembelajaran tersebut di dunia nyata dan mampu mengembangkan kemampuan lain yang menjadi tujuan dari pembelajaran matematika[8]. Pemahaman terhadap konsep-konsep matematika merupakan dasar untuk belajar matematika secara bermakna. Namun pada kenyataannya banyak siswa yang kesulitan dalam memahami konsep matematika. Bahkan mereka kebanyakan tidak mampu mendefenisikan kembali bahan pelajaran matematika dengan bahasa mereka sendiri sertamembedakan antara contoh dan bukan contoh dari sebuah konsep.

Untuk mencapai pemahaman kosep siswa dalam pembelajaran matematika dapat menerapkan model pembelajaran Number Head Together (NHT). Model pembelajaran NHT merupakan suatu model pembelajran berkelompok yang setiap anggota kelompok bertanggung jawab atas tugas kelompoknya, sehingga tidak ada pemisah antara siswa yang satu dengan siswa yag lain dalam satu kelompok untuk saling memberi dan menerima antara satu dengan yang lainnya[9]. Model pembelajaran Number Head Together (NHT) ini merupakan tipe pembelajaran kooperatif yang terdiri atas empat tahap yang digunakan untuk meriview fakta-fakta dan informasi dasar yang berfungsi untuk mengatur interaksi siswa. Model Number Head Together (NHT) ini memberikan kesempatan siswa untuk saling membagikan ide-ide dan pertimbangan jawaban yang paling tepat, dan mendorong siswa untuk meningkatkan semangat kerja sama mereka. Ada 4 fase dalam model pembelajaran NHT yaitu[9]:

Tabel 1 fase-fase pembelajaran kooperatif tipe NHT

\begin{tabular}{|c|l|}
\hline Fase & \multicolumn{1}{|c|}{ Kegiatan Guru } \\
\hline Fase 1. Penomoran & $\begin{array}{l}\text { Guru membagi siswa dalam kelompok 3-5 orang dan tiap } \\
\text { anggota kelompok diberikan nomor antara 1 sampai 5 }\end{array}$ \\
\hline $\begin{array}{c}\text { Fase 2. Mengajukan } \\
\text { pertanyaan }\end{array}$ & $\begin{array}{l}\text { Guru mengajukan sebuah pertanyaan kepada siswa. Pertanyaan } \\
\text { dapat bervariasi. }\end{array}$ \\
\hline Fase & \multicolumn{1}{|c|}{ Kegiatan Guru } \\
\hline Fase 3. Berfikir bersama & $\begin{array}{l}\text { Siswa menyatukan pendapatnya terhadap jawaban pertanyaan } \\
\text { itu dan meyakinkan tiap anggota dalam timnya mengetahui } \\
\text { jawaban tim. }\end{array}$ \\
\hline Fase 4. Menjawab & $\begin{array}{l}\text { Guru memangil suatu nomor tertentu, kemudian siswa yang } \\
\text { nomornya sesuai mengacungkan tangannya dan mencoba untuk } \\
\text { menjawab pertanyaan untuk seluruh kelas. }\end{array}$ \\
\hline
\end{tabular}

Model pembelajaran ini juga dapat digunakan untuk meningkatkan penguasaan akademik siswa Number Head Together (NHT) sering disebut berfikir secara kelompok yang digunakan untuk melibatkan lebih banyak siswa dalam menelaahmateri yang tercakup dalam suatu pelajaran dan melihat pemahaman konsep siswa tersebut. Model kooperatif tipe Numbered Head Together (NHT) memiliki kelebihan dan kekurangan. Kelebihan dari model NHT yaitu, siswa menjadi antusias dan bertanggung jawab dalam belajar, karena siswa memiliki nomor di kepala masing-masing, siswa menjadi lebih aktif untuk berpendapat, bertanya dan menjawab pertanyaan dan sebagainya. Sedangkan kekurangannya yaitu waktu yang digunakan agaklah lama sehingga tidak semua siswa mendapat kesempatan untuk menjawab[10]. Melalui model pembelajaran NHT diharapkan dapat meningkatkan kemampuan pemahaman konsep siswa khususnya materi kubus dan balok dengan berbantuan software. Software yang digunakan adalah software autograph. Software Autograph adalah program khusus yang digunakan dalam pembelajaran matematika. Autograph memiliki 
Hal. 26-32

kemampuan grafik 2D dan 3D untuk topik-topik seperti transformasi, bangun ruang, vektor, kemiringan, dan turunan. Dalam kenyataannya, pengguna dapat mengamati bagaimana fungsi, grafik, persamaan, dan perhitungan. Autograph dapat digunakan untuk menggambar grafik statistik, fungsi, dan vektor dan untuk mengubah bentuk. Hal ini juga memungkinkan pengguna untuk mengubah dan mensimulasikan grafik, bentuk atau vektor yang sudah diplot untuk mendorong pemahaman konsep. Memadukan model pembelajaran NHT dengan penggunaan software autograph bersamaan akan lebih mudah untuk meningkatkan kemampuan konsep matematis siswa.

\section{Metodologi Penelitian}

Penelitian ini adalah penelitian Kuantitatif dan metode yang digunakan yaitu metode quasieksperiment. Penelitian ini bertujuan untuk mengetahui pengaruh model pembelajaran Numbered Head Together (NHT) terhadap kemampuan pemahaman konsep siswa. Lokasi penelitian berada di X SMK Teladan Pematangsiantar. Adapun waktu penelitian dilaksanakan pada semester 1 Tahun Pelajaran 2020. Desain perlakuan dapat dilihat pada Tabel 2.

Tabel 2. Desain Perlakuan

\begin{tabular}{|c|c|c|c|}
\hline Kelompok & Tes Awal & Perlakuan & Tes Akhir \\
\hline Eksperimen & $\mathrm{O}_{1}$ & $\mathrm{X}$ & $\mathrm{O}_{2}$ \\
\hline
\end{tabular}

Keterangan:

$X \quad$ : Perlakuan dengan Numberead Head Thogether (NHT)

$\mathrm{O}_{1}$ : Pretest

$\mathrm{O}_{2}$ : Posttest [11]

Sampel pada penelitian ini adalah siswa kelas VIII-B sebagai kelas eksperimen berjumlah 37 siswa. Instrumen yang digunakan dalam penelitian ini adalah tes kemampuan pemahaman konsep sebanyak 5 soal yang digunakan untuk pre-test dan post-test. Analisis untuk pengujian hipotesis menggunakan uji t yaitu Paired Sample t Tetst, namun sebelum dilakukan uji t terlebih dahulu dilakukan uji normalitas dengan bantuan SPSS [12].

\section{Hasil dan Pembahasan Penelitian Deskripsi Hasil Pretest}

Berdasarkan tabel pengelompokan diatas, distribusi frekuensi hasil pretest dengan jumlah siswa 37 orang terlihat pada tabel 3 berikut:

Tabel 3. Distribusi Frekuensi Hasil Pretest

\begin{tabular}{|c|c|c|}
\hline No. & Interval Nilai & Frekuensi \\
\hline 1 & $41-60$ & 0 \\
\hline 2 & $21-40$ & 12 \\
\hline 3 & $1-20$ & 25 \\
\hline \multicolumn{2}{r|}{ Jumlah } & 37 siswa \\
\hline
\end{tabular}

Dari tabel 3 diatas, dapat diketahui bahwa siswa yang memiliki kategori tinggi sebanyak 0 siswa, yang memiliki kategori sedang sebanyak 12 orang siswa dan yang memiliki kategori rendah sebanyak 25 orang siswa.

\section{Deskripsi Hasil Posttest}

Setelah diberi perlakuan dengan menggunakan model pembelajaran Numbered Head Together pada materi kubus dan balok, dilakukan tes akhir (Posttest). Distribusi frekuensi hasil posttest kemampuan pemahaman konsep siswa dapat dilihat pada tabel 4 berikut ini :

Tabel 4. Distribusi Frekuensi Hasil Posttest

\begin{tabular}{|c|c|c|}
\hline No. & Interval Nilai & Frekuensi \\
\hline 1 & $41-60$ & 24 \\
\hline 2 & $21-40$ & 13 \\
\hline 3 & $1-20$ & 0 \\
\hline & Jumlah & 37 siswa \\
\hline
\end{tabular}


Hal. 26-32

Dari tabel 4 diatas, dapat diketahui bahwa siswa yang memiliki kategori tinggi sebanyak 24 siswa, yang memiliki kategori sedang sebanyak 13 orang siswa dan yang memiliki kategori rendah sebanyak 0 orang siswa.

\section{Perbandingan Hasil Pretest dan Posttest}

Perbandingan hasilpretest dan posttest kemampuan pemahaman konsep siswa kelas $\mathrm{X}$ SMK Teladan Pematangsiantar dapat dilihat pada tabel 5 berikut ini :

Tabel 5. Perbandingan Hasil Pretest dan Posttest

\begin{tabular}{|c|c|c|c|c|}
\hline \multirow{2}{*}{ No. } & \multirow{2}{*}{ Kategori } & \multirow{2}{*}{ Interval Nilai } & \multicolumn{2}{|c|}{ Frekuensi } \\
\cline { 4 - 5 } & & & Pretest & Posttest \\
\hline 1 & Tinggi & $41-60$ & 0 & 24 \\
\hline 2 & Sedang & $21-40$ & 12 & 13 \\
\hline 3 & Rendah & $1-20$ & 25 & 0 \\
\hline \multicolumn{3}{|c|}{ Jumlah } & 37 siswa & 37 siswa \\
\hline
\end{tabular}

\section{Hasil Analisis Uji Deskriptif}

Berdasarkan tabel 5 maka dapat dilihat adanya perubahan antara frekuensi pretest dan posttest. Lebih jelasnya dapat dilihat pada diagram batang perbandingan hasil pretest dan posttest dibawah ini :

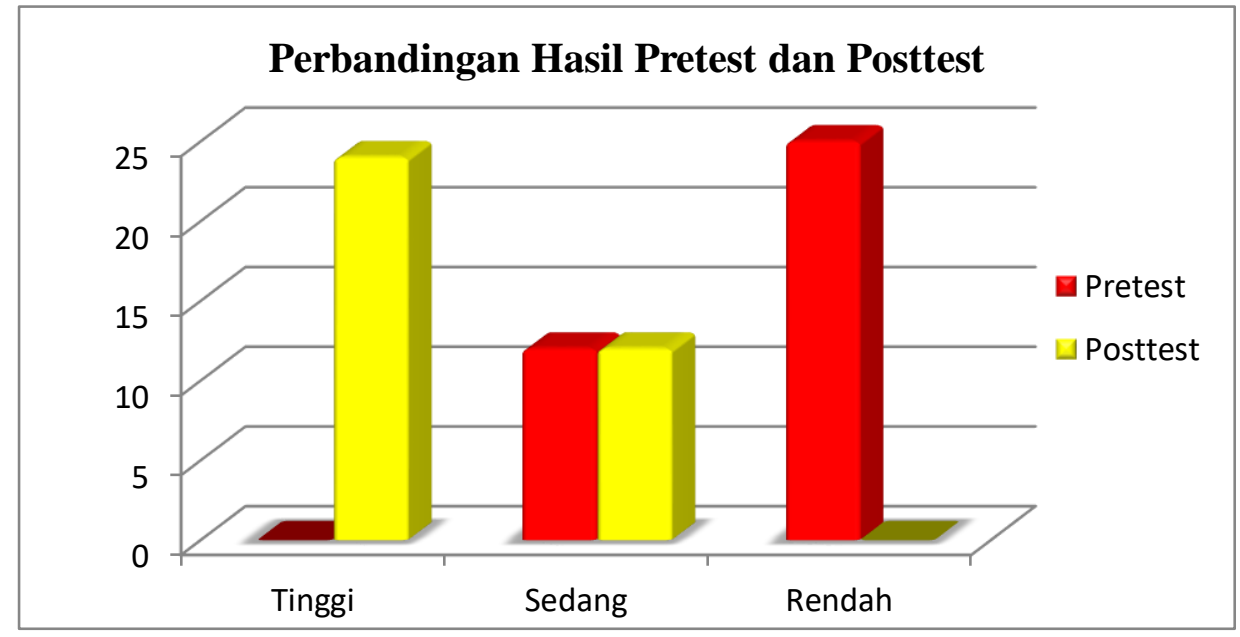

\section{Gambar 1 Perbandingan Hasil Pretest dan Posttest}

Dari grafik diatas, sebelum diberikan perlakuan, siswa yang memiliki kategori tinggi hanya 0 orang, namun setelah diberi perlakuan siswa yang memiliki kategori tinggi menjadi 24 orang. Untuk kategori sedang, sebelum diberi perlakuan ada 12 orang dan setelah diberi perlakuan ada 13 orang. Kemudian sebelum diberikan perlakuan, siswa yang memiliki kategori rendah sebanyak 25 orang, namun setelah diberikan perlakuan siswa yang memiliki kategori rendah hanya 0 orang. Terlihat jelas bahwa perlakuan (treatment) tersebut mempengaruhi hasil yang siswa peroleh.

\section{Analisis Hasil Penelitian}

Berdasarkan perhitungan uji normalitas dengan bantuan SPSS diperoleh nilai $s i g>$ taraf sig $(\alpha=0,05)$ yaitu $0,905>0,05$ yang berarti bahwa data pre-test dan post-test berdistribusi normal. Berdasarkan hasil uji t yang di bantu dengan software SPSS 17 diperoleh nilai sig $<$ taraf sig $(\alpha=0,05)$ yaitu $0,000<0,05$ maka Ho ditolak yang artinya bahwa terdapat perbedaan kemampuan pemahaman konsep siswa setelah diberikan perlakuan model pembelajaran numbered head together.

Demikian dapat disimpulkan bahwa terdapat pengaruh yang signifikan antara model pembelajaran numbered head together terhadap kemampuan pemahaman konsep siswa. Kemampuan pemahaman konsep siswa setelah diberikan model pembelajaran numbered head together mengalami peningkatan, hal ini terlihat dari sebelum diberikan perlakuan, siswa yang memiliki kategori tinggi hanya 0 orang, namun setelah diberi perlakuan siswa yang memiliki kategori tinggi menjadi 24 orang. Untuk kategori sedang, sebelum diberi perlakuan ada 12 orang dan setelah 
Hal. 26-32

diberi perlakuan ada 13 orang. Kemudian sebelum diberikan perlakuan, siswa yang memiliki kategori rendah sebanyak 25 orang, namun setelah diberikan perlakuan siswa yang memiliki kategori rendah hanya 0 orang.

\section{Pembahasan Penelitian}

Berdasarkan pengamatan pada saat meneliti di kelas VIII-B yang berjumlah 37 orang. Dapat dilihat bahwa siswa dituntut untuk mampu memahami konsep dengan Model Pembelajaran Numbered Head Together (NHT) dimana soal-soal yang diberikan berupa soal yang bersifat terbuka maupun berupa soal cerita. Pada akhirnya siswa dapat menjawab soal-soal Model Pembelajaran Numbered Head Together (NHT) dengan mengembangkan kemampuan pemahaman konsep yang mereka miliki dengan bantuan guru atau mendiskusikan dengan teman sekelompok.

Berdasarkan hasil pengolahan data yang telah dilakukan peneliti, skor sebelum diberi perlakuan dan skor setelah diberi perlakuan terdapat perbedaan. Hal ini terlihat dari hasil pengujian hipotesis dengan uji untuk Paired Samples T-Test sampel yang berdistribusi normal diperoleh bahwa nilai Sig.(2-tailed) < taraf $\operatorname{sig}(\alpha=0,05)$ yaitu sebesar $0,000<0,05$ maka $\mathrm{H}_{0}$ ditolak dan $\mathrm{H}_{\mathrm{a}}$ diterima dengan kata lain terdapat pengaruh Model Pembelajaran Numbered Head Together (NHT) terhadap kemampuan pemahaman konsep siswa pada materi kubus dan balok.

Selain itu kemampuan pemahaman konsep siswa juga mengalami peningkatan, hal ini dapat dilihat dari skor yang diperoleh siswa, pada soal pretest skor siswa dengan kategori tinggi hanya 0 orang, sedangkan pada soal posttest skor siswa dengan kategori tinggi sebanyak 24 orang. Untuk skor kategori rendah pada soal pretest sebanyak 12 orang dan pada soal posttest hanya 13 orang siswa. Hal ini juga diperkuat dengan kemampuan pemahaman konsep siswa setelah menggunakan model Numbered Head Together (NHT) pada materi kubus dan balok, kemampuan pemahaman konsep siswa setelah menggunakan model Numbered Head Together (NHT) pada materi kubus dan balok setelah mendapatkan perlakuan (treatment) lebih baik daripada sebelum mendapatkan perlakuan (treatment).

Oleh karena itu, setelah diberi perlakuan terdapat peningkatan atau dengan kata lain skor posttest lebih tinggi dibandingkan skor pretest. Berarti Model Pembelajaran Numbered Head Together (NHT) mempengaruhi kemampuan pemahaman konsep siswa. Dengan demikian penelitian pengaruh Model Pembelajaran Numbered Head Together (NHT) terhadap kemampuan pemahaman konsep siswa pada materi persamaan kubus dan balok mampu menjawab hipotesis yang diajukan melalui analisis data-data yang diperoleh yaitu penelitian membuktikan bahwa terdapat pengaruh Model Pembelajaran Numbered Head Together (NHT) terhadap kemampuan pemahaman konsep siswa.

\section{Kesimpulan}

Berdasarkan hasil penelitian dan pembahasan dapat disimpulkan bahwa terdapat pengaruh Model Pembelajaran Numbered Head Together terhadap kemampuan pemahaman konsep siswa pada materi kubus dan balok. Hal ini dapat dibuktikan dari hasil uji hipotesis menggunakan uji t yang menyatakan nilaiSig. $(2$-tailed $)<$ taraf sig $(\alpha=0,05)$ yaitu $0,000<0,05$, maka $\mathrm{H}_{0}$ ditolak dan $\mathrm{H}_{\mathrm{a}}$ diterima. Kemampuan pemahaman konsep siswa setelah diberikan model pembelajaran numbered head together mengalami peningkatan, hal ini terlihat dari sebelum diberikan perlakuan, siswa yang memiliki kategori tinggi hanya 0 orang, namun setelah diberi perlakuan siswa yang memiliki kategori tinggi menjadi 24 orang. Untuk kategori sedang, sebelum diberi perlakuaada 12 orang dan setelah diberi perlakuan ada 13 orang. Kemudian sebelum diberikan perlakuan, siswa yang memiliki kategori rendah sebanyak 25 orang, namun setelah diberikan perlakuan siswa yang memiliki kategori rendah hanya 0 orang.

\section{Daftar Pustaka}

[1] Mufidah, Arum Dahlia. 2016. Pengaruh Pembelajaran Kooperatif Tipe Core Terhadap Kemampuan Pemecahan Masalah Matematika Siswa Pada Kelas Viii Semester Genap Smp Negeri 10 Bandar Lampung Tahun Pembelajaran 2015/2016. Skripsi. Universitas Lampung Bandar Lampung.

[2] Harahap, H.S., Hrp, N.A., Nasution, I.B., Harahap, A., Harahap, A., Harahap, A. 2021. Hubungan Motivasi Berprestasi, Minat dan Perhatian Orang Tua Terhadap Kemandirian Siswa. Edukatif : Jurnal IImu Pendidikan Volume 3 Nomor 4 Tahun 2021 Halm 1133 - 1143

[3] Priawan, I Made. 2015. Pemecahan Masalah Matematis Pada Materi Persamaan Dan Pertidaksamaan Linear Satu Variable Di Kelas Vii Smp Negeri 1 Batudaa.Skripsi.Jurusan Matematika FMIPA Universitas Gorontalo.07 Mei 2017. 
Hal. 26-32

[4] Siregar, S.U. (2016). Perbandingan Hasil Belajar Matematika Siswa Menggunakan Pembelajaran Kontekstual Tipe VAK (Visual Auditory Kinestetik) dengan Pembelajaran Kooperatif Tipe ATI (Aptitude Treadment Interaktion) pada Pokok Bahasan Bangun Ruang Kubus di Kelas VIII SMPN 1 Rantau Selatan. Jurnal Pembelajaran dan Matematika Sigma (JPMS). Vol. 2 No.1, hIm. 23-25. 2016

[5] Hrp, N.A., Rahma, I.F. 2020. Keefektifan Penerapan Model Pembelajaran Berbasis Proyek Dalam Pencapaian Aspek Kemampuan Representasi dan Komunikasi Matematis Siswa Kelas VI SD Negeri 118296 Beringin Jaya Pinang Damai. Jurnal Pendidikan Matematika (Phi). Vol. 4 No. 2 Tahun 2020

[6] Sanjaya, Wina. 2011. Strategi Pembelajaran Berorientasi Standar Proses Pendidikan. Jakarta: Kencana Prenada Media Group

[7] Sumarmo, U. (2012). Kemampuan dan Disposisi berpikir logis, kritis, dan kreatif Matematik (Eksperimen terhadap siswa Sma Menggungakan Pembelajaran berbasis masalah dan Stategi Think-Talk-Write). Jurnal Pengajaran MIPA. 17(1). 17-33.

[8] Murizal, Angga dkk. 2012. Pemahaman Konsep Matematis Dan Model Pembelajaran Quantum Teaching. Jurusan Matematika FMIP UNP. Jurnal Pendididkan Matematika Vol. 1 No. 1

[9] Shoimin, Aris. 2014. 68 Model Pembelajaran Inofatif Dalam Kurikulum 2013. Jakarta: Ar-Ruzz Media

[10] Hasibuan, L.R. 2016. Perbandingan Kemampuan Pemahaman Konsep Matematis Siswa yang Memperoleh Pembelajaran Cooperative Type Numbered Head Together (NHT) dengan yang Memperoleh Pembelajaran Konvensional pada Siswa SMP Negeri 3 Rantau Utara. Jurnal Pembelajaran dan Matematika Sigma (JPMS). Vol. 2 No.2, hlm. 13-18 (2016)

[11] Sugioyono. 2010. Metode Penelitian Kuantitatif Kualitatif dan R\&D. Bandung: Alfabeta

[12] Siregar, Syofian. 2011. Statistic Deskriptif Untuk Penelitian Dilengkapi Perhitungan Manual Untuk SPSS Versi 17. Jakarta: Rajawali Pers 